\title{
Content Analysis of Nishapur Pottery Inscriptions of the Samanid Era in Terms of Professional Ethics ${ }^{i}$
}

\author{
Reza Panahi ${ }^{1}$, Ali Asghar Salahshour ${ }^{2, *}$ \\ ${ }^{1}$ Handy Crafts, Art University of Isfahan, Isfahan, Iran \\ ${ }^{2}$ Archaeology, Art University of Isfahan, Isfahan, Iran
}

\section{Email address:}

aliasgharsalahshoor@yahoo.com (A. A. Salahshour)

${ }^{*}$ Corresponding author

\section{To cite this article:}

Reza Panahi, Ali Asghar Salahshour. Content Analysis of Nishapur Pottery Inscriptions of the Samanid Era in Terms of Professional Ethics. International Journal of Archaeology. Vol. 4, No. 4, 2016, pp. 78-86. doi: 10.11648/j.ija.20160405.14

Received: July 31, 2016; Accepted: August 12, 2016; Published: August 29, 2016

\begin{abstract}
Professional ethics establish the moral tenet of the various Profession. The mentioned role was appeared in the "Chivalry-letters" (Fotovvat-Nâmeh) of crafts in the traditional society. The theme of the Nishapur pottery inscriptions is so close to the tenet of the Chivalry-letters. Therefore, it can be presumed that they are two branches from a unit source. Some researches have done about the efficacy of ethics on traditional arts and the relation between art and chivalry. But, no research focused on the ethic in Nishapur inscribed pottery has been found. Hence, this study attempts to reveal the impact of morality and its occurrence manner through the analyzing scrolls content in terms of professional ethics and chivalry-letters. By the studying this effect, it be determined that Nishapur pottery has been used as a tool to convey moral messages. The artist was bound by ethics and promotes it. This way of dealing with pottery ends to the moral community finally. The research method was descriptive - analytical and data requirement is collected through library information.
\end{abstract}

Keywords: Samanid Era, Nishaur Pottery Inscriptions, Chivalry-Letter (Fotovvat-Nâmeh), Professional Ethics

\section{Introduction}

Samples of Nishapur Pottery inscriptions during the Samanid era of Iran in the Islamic period are the unique works of art. Emergence of Nishapur pottery inscriptions in this era has been for various reasons: Including Arabs residence in the region, foreign influences and the central government Abbasi reaction against the Samanids who were trying to retrieve the Persian language (Volov 1966). Regardless of the reason for the emergence of this work, a common issue in all of pottery works is the existence of ethics and moral terms. Cotents of scrolls have many contiguity to the concepts of chivalryletters of traditional society crafts. Chivalry- letters were determined the principles of professional ethics that the craftsman in act is bound to them. These two effects can be considered equivalent actions that during the history has been terminated frome pottery Nishapur to written chivalry- letters. Ethics is an issue that is present in most of the scrolls on pottery Nishapur and professional ethics is a theme of chivalry - letter of the crafts of traditional society. Pottery for daily use, is an appropriate tool for the diffusion of any message. Based on the principles of professional ethics, artists in their work can not mention and emphasize ugliness and evils, as well as in the Islamic world view, he is prohibited from doing so. The emergence manner of professional ethics in writing Nishapur pottery inscriptions is an issue that has not been deal with. In this regard, this research is based on following questions:

- What impact had the professional ethics on Nishapur ceramics?

- Moral and ethical contents, How have been appeared the Nishapur pottery inscriptions in the Samanid era?

This article is written in a few words. First, ethics and professional ethics are defined and then, chivalry- letters as the tenets of professional ethics have been studied in traditional society. In the end, after the introduction of inscribed pottery of Nishapur in the Samanid era, ways of appearance of professional ethics is discussed in the scrolls.

\section{Research History}

The study is divided into two parts. Some is proceeded 
ethical issues and partly is discussed about Nishapur pottery in the Samanid era. "[Ameli (2005)] about professional ethics has paid to conditions and it's different approachs as a branch of ethics". Also "[Ameli (2009]) is examined Various theories of ethics and professional ethics". "[Gharamaleki (2001)] has collected Works of different authors such as art in the case of professional ethics in various fields". Chivalry - letters Were determined moral principles of traditional society crafts, also had insight of professional ethics on them. "[Afshari (2003)] has collected 30 chivalry- letters and booklet of khaksariyeh". Some of them auch as tonsorial chivalry - letters, butchers chivalry - letters, cooks chivalry- letters and etc, are related to this research. The second part of the research will be included Nishapur pottery and its inscriptions. "[Wilkinson (1974) \& Kambakhsh Fard (1970)] have published a detailed report of Nishapur excavations". "[Fahrevary (2000) \& Tohidi (2008)] provide technical information and production of these wares". Away from the history of Nishapur ceramics, "[Ghouchani (1985)] has read 140 of pottery vessels". Also "[Ghouchani (2001)] in a paper is extracted statements of attributed to Imam Ali and his expressions from Nisahpur pottery insciptions". "[Mousavi (2011)] knows chivalry letters from important factors for the recognition of Islamic art history and proceed relationship between the gravers chivalry - letters and graving (Ghalamkari) art". Researches have been done About professional ethics in art and the relationship between chivalry- letters and traditional arts, but specifically haven't been found appropriate studies about ceramic and Nishapur pottery in the Samanid era. Therefore, in this research is contemplated the issue of professional ethics and condition of it's appearrance on the scrolls.

\section{Morality and Ethics}

Ethics is plural of Kholgh (mood) and Khologh and it means mood, nature, liability and humanity (Dehkhoda 1993: 1296). During the ethics history, ethical theories have emerged under different titles such as teleological, deontological, realism and non-realism and their subgroups by Western and Islamic scholars and several definitions have been provided for ethics knowledge.

"[Ibn - Miskuyeh in the book of Tahzib Alakhlaq and Tathir Alaraq (1920: 2-3)] says: Mood is condition for human spirit that stimulate him to without thinking and deliberation to works. "[Khwaja Nasiroddin Tousi (1967: 14)] is known ethics, knowledge of the acquisition good moral that based on it, the person deeds and moods become good". According to the moral book, such as meraaj al- Sa'adah can be said that the ethics knowledge from Islamic scholars point of view, is science that discuss about good and bad features and identify them and define, also describe traits of good qualities and virtues acquisition as well as quality of eliminate bad traits (Naraqi 1946). "[Ibn Sina (2004: 3)] has mentioned ethics as a self - knowledge, because he is believed that the ethics speaks about the human soul". Allameh Tabatabai believe "ethics knowledge is technic that argue about human characteristics; characteristics that are related to his/her vegetal, animal and human features. The aim of this discussion is that separate the virtues from vices; It means that this knowledge will determine which features of human are good and cause his/her perfection and virtue and which features are vice and bad and causes his/her failure to human identify them and he/she can adorn himself/herself with virtues and leaves vices" (Tabatabai 1995: 558). Goal and aim of morality is cognition of virtue and condition of utilization them for self-purification and identification of filths and evils in order to clear their souls; for this reason, researchers have named ethics as a conduct science or edification or practical wisdom (Saliba 1992: 20).

\section{Professional Ethics}

Kant Knows ethics, "targeted engagement" and distinguishes it from work and thus defines it: "a profession that is associated with special problems". He also described the work, "set of actions that is doing by human through help of brain, hand, machine and tools for the practical use of material and these actions, mutually, will affect the human and change him" (Kant 1999: 236). Chadwick believe profession in general, only includes "the work and craft and the limited meaning it includes certain activities that would lead to a set position with a certain moral" (Cahdwick 1998: 733).

But in Iranian traditions can be found different views about the professional categories. In traditional letters we face with this definition of the craft: the craft is not only business, but anything that people do. Work must be done good to craftmans can benefit from it.

Generally as for these two views can say profession is more common than work and profession includes concept of work, but all of work instances doesn't include profession. Difference of the profession in the tradition and modernity is in their development of qualitative and quantitative. It is always considered the traditional professional derived from principles, so its qualitative aspect of this is that the components of the tradition and the tradition is considered by the partnership. In other words, activity precisely includes the sacred character and for this reason that have said in such a civilization every job is a spiritual task (Guenon 2008). However, this aspect of the profession with modernity development gradually fade and job forms with quantitative sense.

The main element of each profession is the capital. In traditional society, capital has two means: material and spiritual. Material assets are facilities, equipment, natural resources and any implications are clear. But spritual capital has considerable notions. for example, from spiritual capitals can be mention the principles of behavior and ethics of different professions. Professional ethics is a branch of moral science that requires professional understanding of theoretical concepts, especially its new concepts. Today, with the advancement of human civilizations and the development of social and international communications, concept of profession has changed that disparts it from the traditional concept (Ameli 2005).

Making ethics in relation to individuals, corporatisms and 
social environment, is created several issues, so that it can't expect that the same behavior exists in all human beings. As well as ethics always is bound and obligated within the context of social issues such as family, class, profession and etc. In the definition of professional ethics or business ethics, some of researchers have known it common behavior among those who have taken a career (Sadri Afshar 1994: 67). According to this definition, every profession has distinctive professional ethics that is different from other professions.

This is another definition of professional ethics: "The ethics of a certain profession, a law is which set the acts by it and as well as denotes standards for their people" (Ameli 2009). Based on this definition can be found in different occupations and professions with set out of the ethical rules of the profession's ethical issues as for regulations and interests related to the profession and prepare the way for the profession's determinate goals.

Gharamaleki believe that "professional ethics is moral and corporate obligations that organization has against the direct and or indirect environment" (Gharamaleki 2001: 1). According to this definition, can use this knowledge in organizational relations and community as well as the manner of attitude and performance of the organizational persons as a environment of social, cultural and etc. or if the term of morality refers to a certain tribe, indicates tribe's specific behavior (Saliba 1987: 121). Finally, we can say that professional ethics is knowledge that examines ethical obligations and the profession's ethical works.

\section{Chivalry-Letters}

With the development of human societies, groups and professional societies and unions formed. Thus, among the masses, some of the coworkers and counterparts assemble together and set guidelines and corporatisms and ethical regulations and considered itself bound by duty (Ameli 2009). In the past behavioral and ethical principles of the different professions had composed in the format of chivalry-letters and magnanimity ethics.

Magnanimity means generosity that is rooted in the word of Fata (chivalrous). Fetyān were a group with specific tenet that encompasses spirituality, a spirituality that pervades in the spiritual world and covers all cases and aspects of life and gives it soul. Magnanimity in Islam is ethical sect that leads to regeneration and brotherhood among people and recalling the virtues, courage and avoidance of from vices and fear (Corbin 1984: 3). Throughout of history, we observe different group of fetyān that each of them have codified chivalry- letters and have formulated the rules and guidelines of specific tribe and their corporatism (Ibid: 121). Chivalry in the Abbasid period had became kind of Sufism that was considered ideal accomplishment for most young people. This ideal perfection existed in the most of Shiite classes that disagree with the Abbasid government. They modeled style and character of Hazrat- e Ali, and believed to the alleged of "no chivalrous except Ali, no sword except Zulfaqar" (Zarrinkub 1978: 335).

Chivalry- letters have recorded in various forms. Some, like chivalry - letter Abu Abdul Rahman Salma (d. 412 AH) that written with mystical vision and is explained principles and tenet of this faith. Based on this work, chvalry- letters is a set of virtues of good moral chivalry as honesty, dedication, helping others and so on (Karami pour 2013). In the chivalry letters of a library in Frankfurt after the Miyan Bastan (Kamar bastan or unlimber) of Salman by Imam Ali and mention of Miyan Bastan among seventeen people by Salman, the Miyan Bastan prayer is said. In this prayer seven propositions with their negative oppositions are present. This prayer closes seven things and opens seven things: first closes stinginess and opens generosity. Second closes ignorance and opens knowledge. Third closes greed and opens generosity. fourth closes satiating and opens hunger. Fifth closes satan way and opens God way. sixth closes door of grudge and opens door of patience, And seventh closes door of envy and opens door of conscience and intellect (Afshari 2003: 128).

Some of these chivalry- letters are poetic. Such as chivalry - letters of Sayyid, Naseri and Attar (Alagheh 1998). In Attar poetic chivalry- letters, there are seventy-two conditions for the magnanimity. Such as truth, freedom from the bondage of self, fidelity, forgiveness and etc (Attar Nishapuri 2005). A group of chivalry- letters have been written by the owners of some of crafts in adaptation various stages of profession with magnanimity tenet and pertaining to these acts of generosity and elders and saints of God. Among the different corporatism and ethical regulations can mention indicator works such as, tonsorial chivalry - letters, blacksmiths chivalry - letters and etc (Afshari 2003: 2).

The common point that can be seen in all of the chivalryletters, are attention to ethical issues, foundation of personal and professional life based on them. Therefore, can be said traditional society of Iran was moralist society and chivalryletters were a foundation for life in this society. Dependence to the moral principles is sometimes considered far beyond of the professional skills. In the Hajjaman (or bloodletters) chivalryletter is follows thus: If person doesn't read the business career or doesn't hold it by himself, his business isn't lawful and the Day of Judgment will take account of this business (Afshari 2003: 101). And who read it, will pass him. And in the chivalry-letter of shoe makers, is emphasized on having business career, although the business owner can't read it. (Ibid: 62).

The emphasis on the chivalry faith and morals, is frequently mentioned in the context of chivalry- letters. Meditate on these principles can be expressed the traditional craftsman had bound defined principles in himself/herself profession and according to these principles was responsible towards society. Location of the responsibility is his products and services. So chivalry- letters not only are a sanctification and spiritual history of profession but also include the profession's procedure rule and its moral statement. In traditional society, the artist-craftsmans were not apart from the artisans. With survey of handycrafts and pottery in particular, we can observe ethics in the production of potteries. The importance of ethics in pottery is for this reason that most products of daily consumption are ceramic. The widespread use leads to 
moral statements in the form of inscriptions on potteries of the Samanid era. However, most of chivalry- letters have been written years after the fall of the this dynasty, but it is not inconceivable that these texts are rooted in insights such as, writing of specific terms on pottery and in its continuation have been created.

\section{Nishapur Inscribed Pottery}

Historical documents show the antiquity of Nishapur. In the inscriptions of Shapur I in the Ka'ba-i Zardusht at Naqsh-i Rustam, Nishapur is referred as the "Tamam Aparkhshtar" (Sami 1963: 47). Nishapur name on Sasanian coins is inserted as the "Apar" and the Arab Sasanian coins as the "Aparash". After triumph of Nishapur in the first century AD by the Arabs (Ibn al- athir 2006: 1655) and arrival of Islam and its concepts, the city begins a new chapter in art and civilization (Basafa 2006). During the Abbasid period (132-656 AH.) preliminary of formation of cultural and political centers of the Islamic world prepared in the East. Nishapur in this period was capital of Taherian dynasty and in second century AH was important bases followers of Imam Ali (Etezadi 1995: 563). The important peak of the city is considered in the Samanid era (Rice 1996: 55). Samanid era is rebirth of art and literature in Iran and a number of royal rulers of that time, were supporters of the arts and artists (Shratu 2005: 50; Volov 1966). Different arts in this period reached a new position and share of potters is innovation and evolution of the "painted pottery of Glabeh" I(Atai et al. 2002). Many of the potteries have been found in archaeological excavations at Nishapur and experts have attended to them. Classification of the potteries have been taken from decorating techniques, color (Wilkinson 1974) and kind of painting point of view (Watson 2004: 205-251). In any case of the categories, the inscribed pottery is observed as a particular category.

The rise of Islam and new ideas related to it, as well as writing the Qur'an prepared arena for the importance of calligraphy as an important art, so that a beautiful handwriting was as a master in the art (Froom 2008: 15). Using calligraphy for more Islamic arts, appeared branch as the scroll in the Islamic art. Islamic scroll on clay, at least begins from the early second century AD. In this century, the first Islamic typical vessels appear. What distinguishes these inscribed vessels is Kufic that is the best criterion for the diagnosis of this group of potteries with pre-Islamic periods (Blair 1998: 151). Most of the scrolls have been discovered from centers such as Bukhara, Jorjan (Gorgan), Samarqand and Nishapur. Most of the vessels are buff or red bowl and plate covered with white colour (Ibid: 152). In the most importatnt vessels, inscription is executed in black on a white background and Nishapur was an important center for manufacturing of this type of pottery.

Scrolls writing style reflects the relationship with God that

I In this way, vessels have a Glabhie's backround that decorations are created by painting on it. Also colours be obtained from a combination of dyes and Glabeh (Blair \& Bloom 2004: 122; Fehervari 2000: 50). resulted in the conquest of the Arabs and the Arabic language had growth and vitality that there was not in the Pahlavi language (Pope 2088: 3151). Most inscriptions third century $\mathrm{AH}$ have been implemented in short term in the corner of the internal edge and bottom of the vessel, but in the fourth century $\mathrm{AH}$, have been accompanied with motifs such as stylized birds and flowers. (Tohidi 2008: 262). The text of the present inscriptions includes traditions of Hazrat-e Mohammad and Imam Ali, proverbs and famous sayings of Hatim al-Tai and other philosophers and scientists at that time and earlier (Ghouchani 1985: 8-12). As well as words such as blessing, welfare, health and etc have been written on potteries.

\section{Ethics in the Inscribed Potteries}

\subsection{The Moral and Ethical Implications Have Appeared in Two Species on the Inscribed Potteries}

\subsubsection{Moral Thought}

Idea is formed in the mind of the artist - artisan and is manifested in terms of prayer and good words on the pottery. At first, there is no moral issue, but in fact target is audience and consumer guide to the lofty life. In fact, it seems when potter was writting scroll, he/she has had ideas of good and moral. With the development of this statement can be extended it to the whole of potter life and total of the potters of Samanid era. Of course some of potters produced them because of sale, commerce and popularity of these potteries.

\subsubsection{Ethical Teachings}

The requisite moral doctrine is primarily a moral idea. The teachings in the scrolls directly or implied have been stated. The scrolls content is clear. Moral thought is rooted in the worldview of the artist and thus caused the worldview of morality. moral thought makes artist, moralizer person and forgive him the choise's power of ethical issues. All interactions between issues of ethics in practical and professional environment of pottery are formative of professional ethics of artists, which resulted in the manufacture of a moral object.

\subsection{Concepts and Ethical Implications Are Classified into Three Groups}

\subsubsection{Ethical Phrases}

These scrolls contain moral themes and expressly state phrases such as contentment and greed, faithfulness, modesty, knowledge and ignorance, generosity and etc. Scribe with praise of good character and despise the ugly traits, or choise of wise sentences containing hidden messages that need to the speculation has conveyed these subjects. These phrases are reminder seven points of quoted in the present chivalry-letter in the University of Frankfurt (already mentioned above). Three species of moral content are visible in Nishapur pottey inscriptions:

(1) Praise of the good traits and denounce of the ugly traits: good and ugly descriptions explicitly have been stated in these 
scrolls. Among expressions of praise can be mentioned "لالوبل

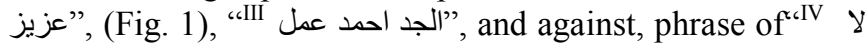
"مصيية الاعظم من جهل ال.رات ليست لها غاية (Fig. 2) that indicate ignorance equal evil.

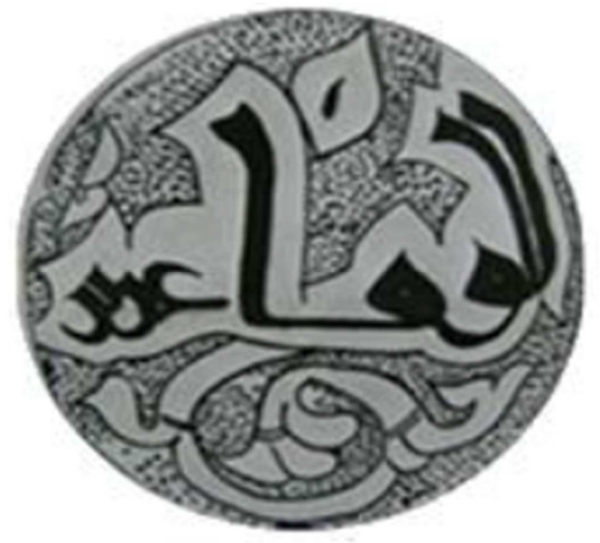

Figure 1. Loyalty is venerable (اله) عزيز) (Ghochani 1985: 284).

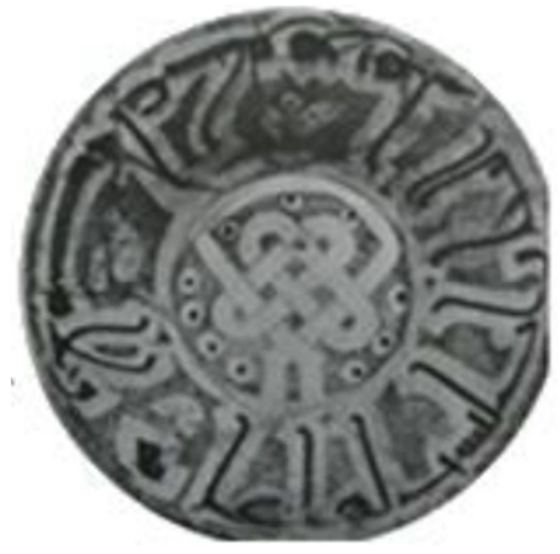

Figure 2. There is no tragedy worse than ignorance of which there is no end (Ghouchani 1985: 88).

(2) Encounter of symbolic and wisdom: recorded expressions in this group also refer to the good and ugly traits. With the exception of that, there are not explicitly of praise and condemnation in them. Instead of clarity, this group has wise words and phrases that have been expressed with elegance and beauty. This wisdom can be realized about special groups and attributes as the righteouses, the dwellers of paradise, chivalrous and freehearted. In this group of inscriptions can be seen phrases like as “V الجود من اخلاق اهل الجنه ". According to this theme, forgiveness and benefaction are characters of paradisaics. This subject in the Sayed chivalry-letter cited by the Hazrat-e Mohammad that stingy and miserly don't enter in the heaven and generous of manly in the fires of hell. Also in this chivalry-letter of magnanimity traits is mentioned avoidance of avarice, envy and greed (Afshari 2003: 11- 13).

\footnotetext{
II Loyalty is venerable

III The best of work is effort

IV There is no tragedy worse than ignorance of. which there is no end.

$\mathrm{V}$ Forgiveness is the attribute of paradisiacs.
}

Other types of inscriptions of this category describes Imam Ali. The Shiites believe that Hazrat-e Ali was a symbol of chivalry and potters with the phrase of "VI لهنى الا على لا سيف لالا "ذو الفقار symbolically, have presented chivalry culture in their work (Fig. 3).

In the chivalry- letter of linear set of the "Mellat Effendi of Turkish", God covered appearance of chivalry to the Hazrat-e Mohammad then the Prophet Mohammad addressed to Imam Ali that the dress only belongs to you and doesn't wear it other person. And phrase of “"لانى الا على لا سيف الا ذو الفقار" from here arises (Ibid: 29). So the fact that Imam Ali is considered a symbol of chivalry and perfection in Shi'a Islam, can be Fata (chivalrous) word to refer to him and can be considered the manifestation of his attributes in the scrolls. Also apply themes of his statements like "the freehearted is freehearted, even when hardship" (Ghouchani 1985: 9).

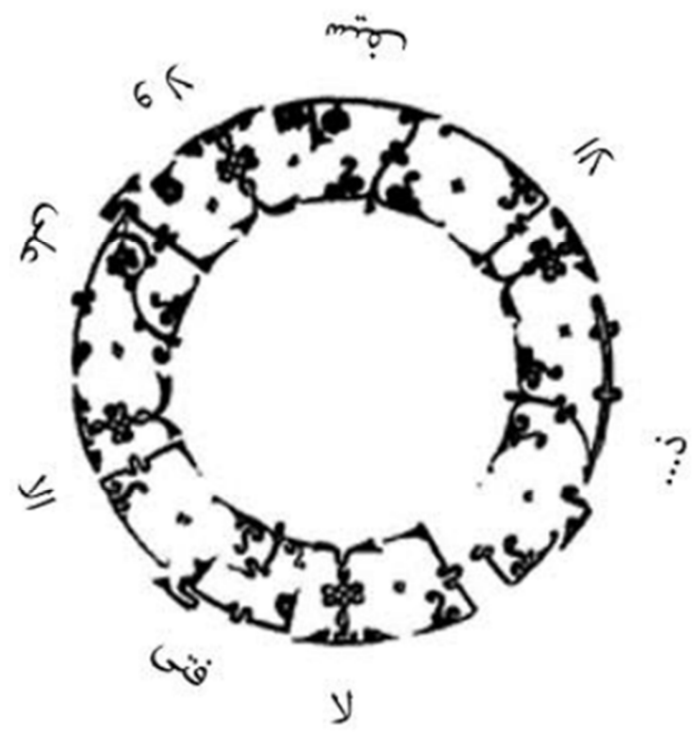

Figure 3. No chivalrous except Ali, No sword except Zulfaqar لالنتى الا على لا (لأل) (Ghouchani 2001: 17).

(3) Order to the good things to achieve qualities in life: Islamic vision has a strong emphasis on enjoinment to good and forbiddance from wrong. This is explicitly stated in the text of the Qur'an and in the many traditions. Enjoinment to good and forbiddance from wrong are traits of believers and is aligned faith in God, prayer and Zakat. In the Qur'an (Al-Imran Sura: 110 Verse) Muslims supremacy over others is mentioned because of good traits possess. "[Imam Ali (NahjAlbalaghe, wisdom of 374)] have compared all of good things and holy jihad in God's way against enjoinment to good and forbiddance from wrong to blowing over the vast sea".

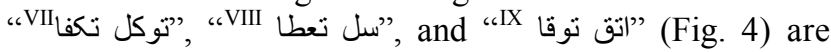
phrases which have specified the target and also have denoted achievement to the target. This goal depends on trust in God's word. Potters advise to trust in God is exemplar of enjoinment

VI No chivalrous except Ali, no sword except Zulfaqar. VII Put your trust in God that he is sufficient for you.

VIII Ask to be given to you.

IX Be virtuous to become successful. 
to good, religious and moral commitment of artist to the society of his time.

" توكل تكفا means put your trust in God that he is sufficient for you that reflects the close concept to third verse of Ahzab

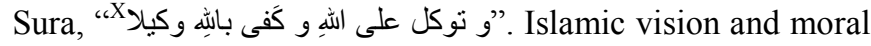
obligation of artist is expressed in this worldview.

\subsubsection{Good Idea}

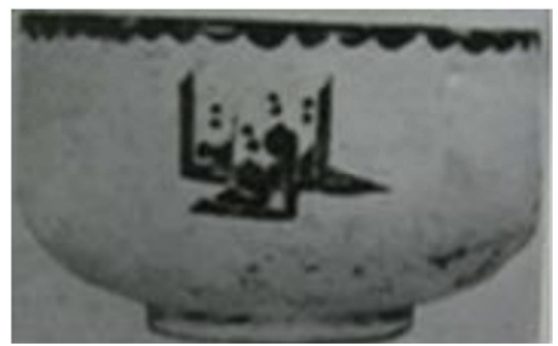

Figure 4. Be virtuous to become successful (اتق توقا) (Ghouchani 1985: 110).

This group of inscriptions has appeared on pottery in two forms:

(1) concepts and examples of good life: The scrolls phrases such as blessing, felicity, joy, health and etc can be seen abundantly. These concepts are at the continuation of a moral statement (Fig. 5) in combination with each other (Fig. 6) and separately (Fig. 7) have been recorded on potteries.

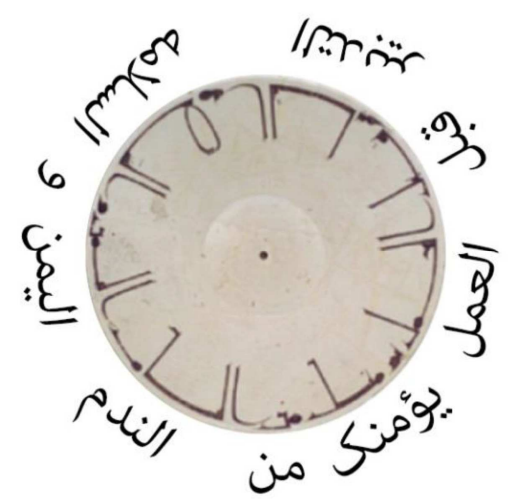

Figure 5. Deliberation before action protects you from regret, blessing and peace (التدبير قبل العمل يومنك من الندم و اليمن و السلامه) (After Panahi 2014).

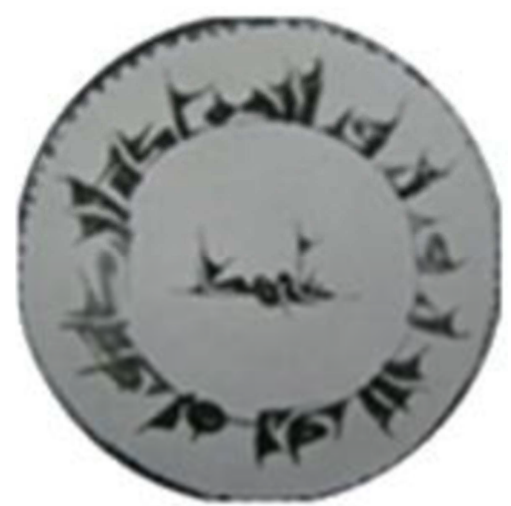

Figure 6. Blessing and happiness, Ahmad (بركه و بمن و سرور و سعاده، احمد ) (Ghouchani 1985: 232).

$\mathrm{X}$ And trust in God, and God is sufficient for the servants.

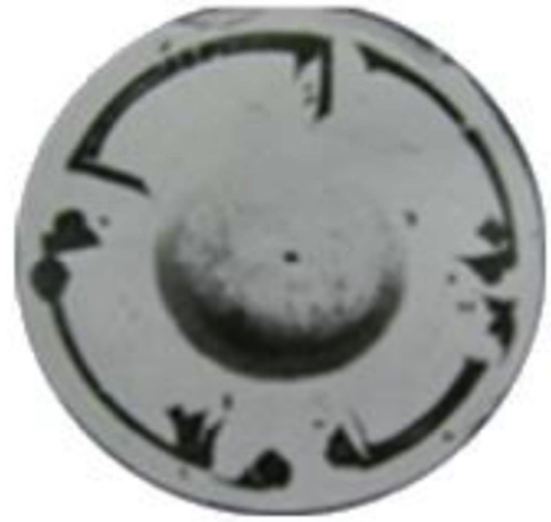

Figure 7. Blessing and benediction for his/her owner (بركه و نعمه لصاحبه) (Ghouchani 1985: 174).

Then, the apply of concepts in continuation of phrase and during the writing can be considered for filling the remaining space, but compared with the other samples from identical sentence that have not these concepts at the continuation (Fig. 5 with expression of “XI اليمن و السلامد" at the continuation of sentence and Fig. 8 without expression at the end of the sentence) and also with confidence in the abilities of epigrapher in writting, can be said that these concept words have been registered and premeditated on the pottery deliberately.

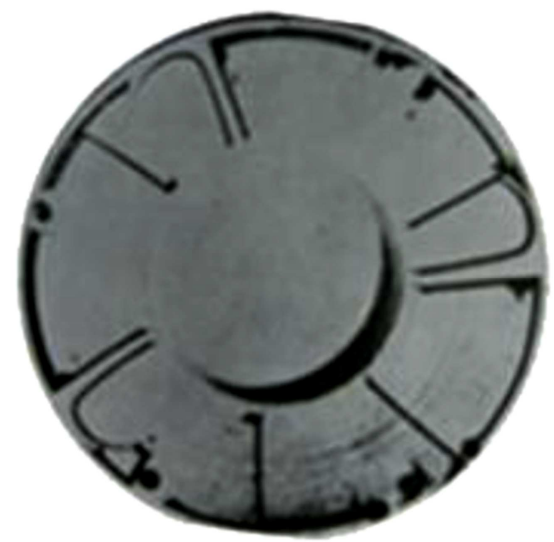

Figure 8. Deliberation before action protects you from regret التدبير قبل العمل) (Ghouchani 1985: 104).

The inscription should be measured in terms of qualitative and not quantitative. Who has the ability to execute the work according to the principles of art and calligraphy, is certainly capable to write limited sentence in the distinctive space. Also, The writing of these concepts in combination with other concepts, or individually, is reason for the existence of good idea and the importance of the problem of writing them. Belief in the word and its supernatural role can justify the use of concepts such as blessing, felicity and happiness. On the other hand, can be realized a form of professional ethics among these concepts.

(2) Noush Nameh: Noush Nameha are the most material of

XI Blessing and happiness. 
aspect of the scrolls contents. And have a concept, and it is

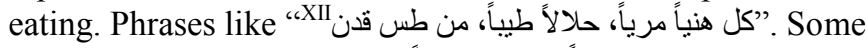
of Noush Nameha such as " "حلانا" "طيباً" " is risen from the Islamic worldview of potter artist and instill a clean piece of bread. The other group such as "من طس قدن ", "كل هنيا مريا" and etc, make pleasant the use of pottery (Fig. 9).

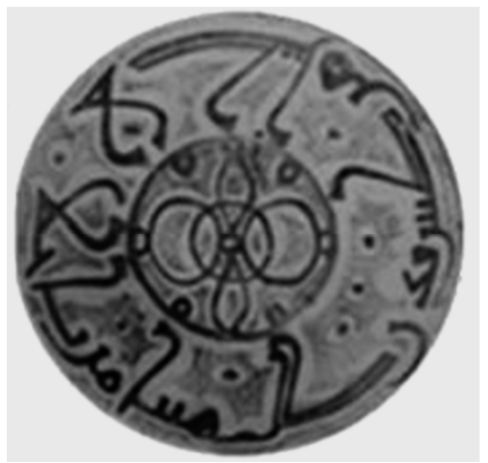

Figure 9. May every thing be whole some, it s permissible and dainty to eat from a bowl that is always full (كل هنيا مريا حلالا طييا من طس قدن) (Ghouchani, 1985: 28).

\subsection{3. الملك لله (Kingdom Belongs to God)}

Among the scrolls, phrase of “XIII لهّ "الملى "istinct from the rest. The emergence of this phrase can be expressed in terms of Islamic ideologybased on monotheistic into the other worldviews and also everything belong him. Religions such as Zoroastrian and Manichean, Christianity and Judaism have attended in this period (Ibn Nadim 2002: 412, 600; Maqdisi 1982: 355). Sixteenth verse of Ghafir Sura in the Qur'an which is as follows: “XIV لمَنِ الملكُ اليومَ اله الواحدِ القهار”. According to this verse, in the Day of Judgment the whole of universe and kingdom belongs to God. The emergence of phrase of " الملى 山े" on the artistic works of Islamic of various dynasties like Mashkul pulpit belonging to the Seljuk period, altar of Aljayto related to Ilkhans is a response to the mentioned question in the previous verse, and is thus humility of Islamic artists such as potter artist versus the lord (Maleki Golandouz \& Mohammadi 2012) (Fig. 10).

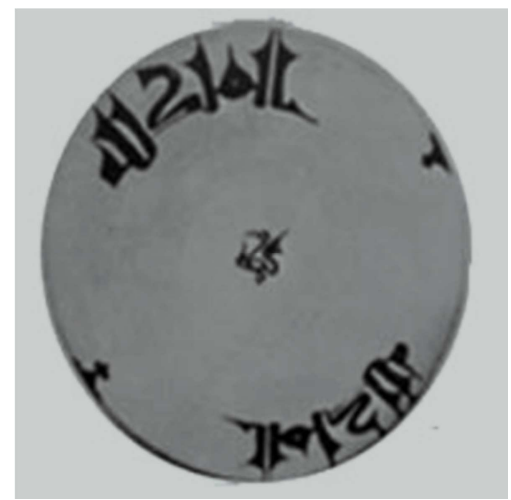

Figure 10. Supreme authority is God ( الملى له) (Ghouchani 1985: 226).

XII May every thing be whole some, it s permissible and dainty to eat from a bowl that is always full.

XIII Supreme authority is God (kingdom belongs to God).

XIV Today whose is the lord? It belong to God the Almighty.
Pottery because of intrinsic characters such as cheap cost, the ability for produce in lesser time than other things, has been at the heart of Nishapur in the Samanid era. Archaeological findings confirm this claim (Wilkinson 1973). Among findings a considerable number of inscribed pottery show the popularity of this group amongst the people. inscription - the main indicator of such potteries - is element that conveys message. So the content, become important. Since ethics is very important in traditional art, ethics has a particular position in the pottery.

It can be said in the society of Samanid era, pottery has been media in the hands of artists that through it has spreated the defined principles in the Islamic worldview and the professional principles of himself/herself craft. Aforementioned points around written phrases verify utilization of pottery as a medium. These principles were written during later centuries as the chivalry- letters and have reached to the present age. The study of recorded contents in Nishapur pottery inscriptions and chvalry- lettes show that they have same origin. Nishapur scrolls because of historical precedence can be known the first movements for observance of the principles of professional ethics in the traditional society. In fact, chivalry- letters are written principles of traditional profession ethics that have been created after the scrolls.

Moral concepts on pottery led to its spread in all of society levels. Because of continual use of pottery these concepts diffiuse amongst consumers. Repeat and remember of these words led to the institutionalization of moral principles in the essence of persons and finally occur the moral health of society. Adherence of artist - artisan to the principles of Islam and eventually his commitment to these principles is other point that result from the presence of these words. It can be said that the commitment to the religious principles, implicates morality.

\section{Conclusion}

Professional ethics is branch of ethics that specifies moral principles and behavioral tenet of different proffesions. In traditional society, chivalry-letters had principles and can be considered them stater of professional ethics of different crafts. Nishapur inscribed potteries that are valuable samples of Samanid art, from content point of view have many resemblance to the recorded principles in the chivalry- letters. We can locate them in a historical way that begin from scroll and terminate to the trade chivalry- letters. In this respect, according to the principles of chivalry - letters, scrolls content analized and can be considered ethical principles as an important factor in writing of Nishapur pottery inscriptions. Because of the high consumption of pottery and conveyor of the written message, Nishapur pottery as a media is used at that time and influenced by the principles of professional ethics of pottery craft, moral principles have appeared with different ways such as praise of goodnesses, condemnation of vice and bad traits, expression of god power and blessings and prosperity for addressee. 
Archaeology findings reveal popularity of inscribed pottery in Nishapur. So it can be realized the presence of ethics fluid and concepts of morality in the society of that time. Repeat and remind led to the institutionalization of moral concepts in the consumers unconscious and ultimately can be described Nishapur society of Samanid era as a moral society. Part of importance in this community is indebted to professional ethics in the pottery craft.

\section{References}

[1] Afshari, M. 2003. Chivalry- letters and Booklet of Khaksariyeh (Thirty Booklet). Tehran: Institute for Humanities and Cultural Studies (in Persian).

[2] Alagheh, F. 1998. "Review of Chivalrouses and Chivalryletters”. Farhang. No. 25, 26: 295-317 (in Persian).

[3] Ameli, M. 2005. "The Evolution of Ethics in Islamic Art". Journal of Kheradnameh Sadra. No. 39: $42-48$ (in Persian).

[4] Ameli, M. 2009. "Theoretical Approach to Professional Ethics". Journal of Pazhuheshnameh Akhlagh. No. 4: 115- 142 (in Persian).

[5] Atai, M., R. Mousavi Haji and R. Koulabadi. 2005. "Glabeh's Painted Pottery (Types, Extent and Chronology)". Negareh Quarterly. No. 23: 70- 88 (in Persian).

[6] Attar Nishapuri, Muhammad ibn Ibrahim. 2005. Poem. Tehran: Scientific and Cultural Publishing Company (in Persian).

[7] Basafa, Hasan. 2006. "Pseudo - Inscriptions of the Early Centuries of Islamic, According to the Findings of Nishapur Potteries". Journal of Bastan Pazhouhi. No. 14: 4-12 (in Persian).

[8] Blair, Sh. 1998. Islamic Inscriptions. Edinburgh University Press.

[9] Blair, Sh. And J. Bloom. 2004. Decorative Arts, In: Islamic Art and Architecture, Ed. by M. Hattstein and P. Delius Konemann, Italy: 118-123.

[10] Chadwick, R. 1998. "Professional Ethics". Encyclopedia of Routledge. Vol. 7. London and New York.

[11] Corbin, H. 1984. The Ethic of Chivalry. Trans. by Ehsan Naraghi. Tehran: Nashr-e Now (in Persian).

[12] Dehkhoda, A. 1993. Dehkhoda Lexicon. Tehran: Center Press of Tehran University (in Persian).

[13] Etezadi, L. 1995. Proceedings of the Congress of Iran Architectural and urbanity. Vol. 1. Tehran: Cutural Heritage Organization [14] Gharamaleki, A. 2001. Regulation of Professional Ethics. Tehran: Defencelesses and Veterans foundation of Islamic Revolution (in Persian).

[14] Fehervari, G. 2000. Ceramics of the Islamic World. I. B Tauris and Co Ltd. London-New York.

[15] Froom, A. 2008. Persian Ceramics from the Collection of the Asian Museum. Asian Art Museum.

[16] Gharamaleki, A. 2001. Regulation of Professional Ethics. Tehran: Defencelesses and Veterans foundation of Islamic Revolution (in Persian).
[17] Ghouchani, A. 1985. Nishapur Pottery Inscriptions. Tehran: Reza Abbasi Museum (in Persian).

[18] Ghouchani, A. 2001. "Manifestation of Imam Ali (AS) on the inscriptions of Nishapur Pottery". Ketab-e Mah-e Honar Journal. Farvardin and Ordibehisht: 17-19 (in Persian).

[19] Guenon, R. 2008. "Old Crafts and New Industry". In: The Dominance of the Quantity and Marks of the End of Time. Trans. by M. Kardan. Ketab-e Mah-e Honar Journal. Month of Mehr: 68-71 (in Persian).

[20] Ibn - Miskuyeh, Abu Ali Ahmad Ibn Muhammad. 1920. Tahzib Alakhlaq and Tathir Alaraq. Printery of Wadi- al Nil Alamerah (in Persian).

[21] Ibn al- Athir, E. 1991. Complete History. Trans. by M. H. Rouhani. Tehran: Asatir Press (in Persian).

[22] Ibn Nadim, Mohammad Ibn Ishaq. 2002. Al- Fehrest. Trans. by M. R. Tajaddod. Tehran: Asatir Press (in Persian).

[23] Ibn Sina. 2004. Daneshname- ye A'layi. Correction by Dr. M. Moin. Tehran: Community cultural figures / Hamedan: Abu Ali Sina University (in Persian).

[24] Kambakhsh Fard, S. 1970. Nishapur Excavations and Pottery of Iran in the Fifth and Sixth Centuries AH. Tehran: Ministry of Culture and Art (in Persian).

[25] Kant, I. 1999. The Lessons of Ethics. Trans. by M. Sanei Darreh Bidi.Tehran: Naghsho Negar Press (in Persian).

[26] Karami Pour. H. 2013. "Survey of the Social Dimensions of Chivalry Ethic at Khorasan from Third Century AH to Sixth Century AH". Journal of Tahghighat-e Oloum-e Ejtemaie. Third year. No. 1: 89-113 (in Persian).

[27] Khwaja Nasiroddin Tousi. 1967. Akhlagh- e Naseri. Correction by A. Tehrani. Tehran: Javidan Elmi Publication (in Persian).

[28] Maleki Golandouz, M., and R. Mohammadi. 2012. "Reviews of Features and Aesthetics of Mashkul Pulpit, Wooden Art Masterpiece of Muslim World”. Negareh journal. No. 23: 4-16 (in Persian).

[29] Maqdisi, Abu Abdullah Muhammad Ibn Ahmad. 1982. Ahsan al-Taghasim. Trans. by A. N. Monzavi. Vol. 1. Tehran: Iran's Authors and Translators Company (in Persian).

[30] Mousavi, R. 2011. "Islamic Art in the Mirror of Chivalry letters with Focus on the Gravers Chivalry- letter". Journal of the studies of Islamic Art. Fifteenth Year. Autumn and winter: 21-34 (in Persian).

[31] Naraqi, M. A. 1946. Meraaj al- Sa'adah. Bookstore Islamiyah (in Persian).

[32] Panahi, R. 2014. "Recognition the Roots of Chivalry on Nishapur Inscribed Pottery (emphasize on Hazrat e Ali's manifestations)". MA thesis, Art University of Isfahan (in Persian).

[33] Pope, A. U. 2008. An Exploration of Iranian Art. (from Pre-history to the Present Day) Under the supervision of A. U. Pope and P. Ackerman. Trans. by N. Daryabandari and et al. Tehran: Scientific and Cultural Publishing Company (in Persian).

[34] Rice, D. T. 1996. Islamic Art. Trans. by M. M. Bahar. Tehran: Scientific and Cultural Publishing Company (in Persian). 
[35] Sadri Afshar, G. H. 1994. Today Persian culture. Tehran: Kalameh Publication (in Persian).

[36] Saliba, J. 1987. Philosophic Culture. Trans. by M. Sanei Darebidi. Tehran: Hekmat Publication (in Persian).

[37] Saliba, J. 1992. Dictionary of Philosophy and Social Sciences. Trans. by K. Barg Nisi. Tehran: Enteshar Press (in Persian).

[38] Sami, A. 1963. Sasanid Civilization. Shiraz: Mousavi Printery (in Persian).

[39] Shratu, U. 2005. Samanid Art. Trans. by J. Azhand. Tehran: Muwla Press (in Persian).

[40] Tabatabai, M. H. 1995. Tafsir al- Mizan. Trans. by M. B. Mousavi. Vol. 1. Tehran: Islamic Publishing Office of the Society of Seminary Teachers of Qom (in Persian).

i This article is elicited from first author's MA thesis entitled "Recognition the Roots of Chivalry on Nishapur Inscribed Pottery (emphasize on Hazrat_e Ali's manifestations)".
[41] Tohidi, F. 2008. Technic and Art of Pottery. Tehran: Samt Publication (in Persian).

[42] Volov, L. 1966. "Plaited Kufic on Samanid Epigraphic Pottery". Ars Orientalis 6: 107-34.

[43] Watson, O. 2004. Ceramics from Islamic Lands. London: Thames and Hudson Ltd.

[44] Wilkinson, C. 1974. Nishapur: Pottery of the Early Islamic Period. NewYork: The Metropolitan Museum of Art.

[45] Zarrinkub, A. 1978. Quest in Sufism in Iran. Tehran: Amirkabir Publication (in Persian). 